\title{
MR findings in acute oculomotor neuropathy, leading to a diagnosis of Sjögren syndrome
}

\section{Figure Coronal T1-weighted images through the brainstem and skull base}
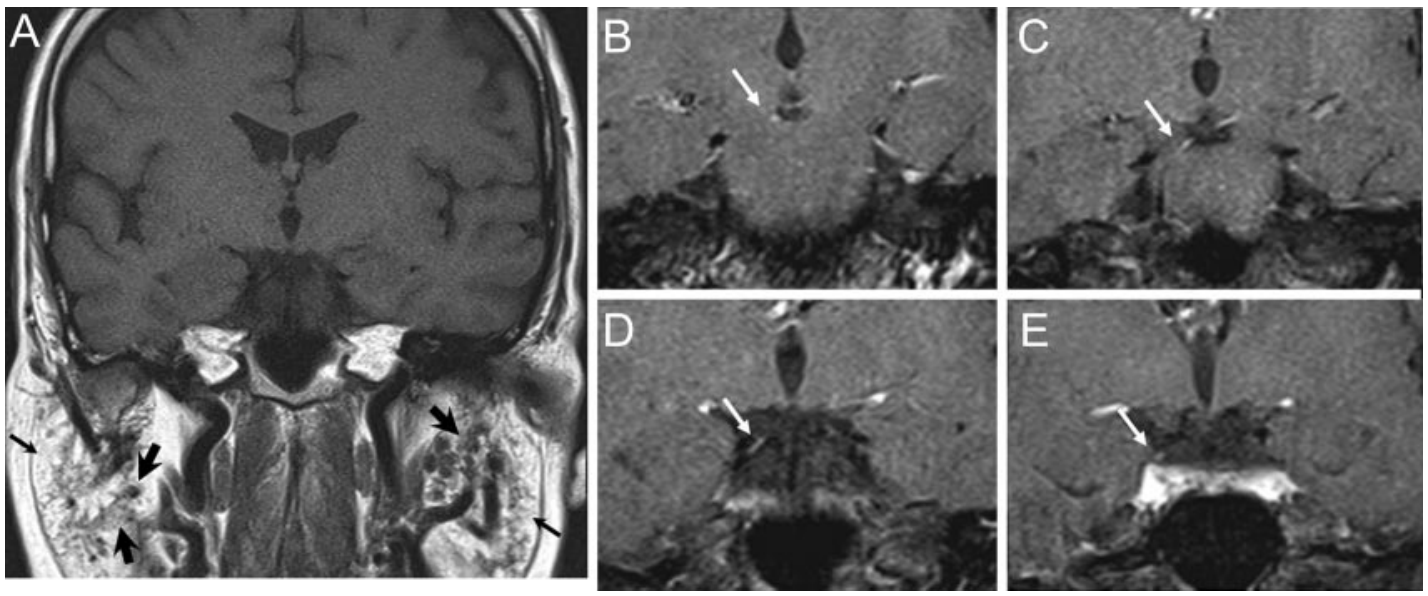

(A) Note the heterogeneous nodular appearance (fat arrows) of the parotids with fatty infiltration (thin arrows). (B-E) Collage of consecutive postcontrast images reveals abnormal enhancement of the right oculomotor nerve (arrows) as it runs its anatomic course from the inter-peduncular cistern to the cavernous sinus.

A 52-year-old woman presented with acute isolated right oculomotor palsy. Contrast enhanced MR showed abnormal enhancement of the right oculomotor nerve (figure), and a heterogenous and nodular appearance of the parotids with prominent fatty infiltration. On questioning, the patient reported recent feelings of dry mouth and eyes. Subsequent investigations revealed a raised erythrocyte sedimentation rate, positive anti-Ro antibody levels, Schirmer test, and minor salivary gland biopsy of the lower lip, confirming the diagnosis of primary Sjögren syndrome. ${ }^{1,2}$ The patient also underwent thorough investigations to exclude other etiologies, including a double stranded DNA for lupus and CSF examination, culture, and cytology; all these were negative. As patients with Sjögren syndrome rarely complain spontaneously of xerostomia and xeroophthalmia, ${ }^{1}$ the incidental parotid MR findings in this patient led to the final diagnosis.

Tze Hern Teo, MD, Norazieda Yassin, MD, Chun Wai Yip, MD, and Ling Ling Chan, MD, Singapore

Disclosure: The authors report no disclosures.

Address correspondence and reprint requests to Dr. Ling-Ling Chan, Department of Diagnostic Radiology, Singapore General Hospital, Outram Road, Singapore 169608, Republic of Singapore; chan.ling.ling@sgh.com.sg

1. Vitali C, Bombardieri S, Jonsson R, et al. Classification criteria for Sjögren's syndrome: a revised version of the European criteria proposed by the American-European Consensus Group C, and the European Study Group on Classification Criteria for Sjögren's Syndrome. Ann Rheum Dis 2002;61:554-558.

2. Soliotis FC, Mavragani CP, Moutsopoulos HM. Central nervous system involvement in Sjögren's syndrome. Ann Rheum Dis 2004;63:616-620. 


\section{Neurology}

\section{MR findings in acute oculomotor neuropathy, leading to a diagnosis of Sjögren syndrome}

Tze Hern Teo, Norazieda Yassin, Chun Wai Yip, et al. Neurology 2008;71;1927

DOI 10.1212/01.wnl.0000336644.54519.93

\section{This information is current as of December 1,2008}

\section{Updated Information \&} Services

References

Subspecialty Collections

Permissions \& Licensing

Reprints including high resolution figures, can be found at: http://n.neurology.org/content/71/23/1927.full

This article cites 2 articles, 2 of which you can access for free at: http://n.neurology.org/content/71/23/1927.full\#ref-list-1

This article, along with others on similar topics, appears in the following collection(s):

All Neuro-ophthalmology

http://n.neurology.org/cgi/collection/all_neuroophthalmology Autoimmune diseases

http://n.neurology.org/cgi/collection/autoimmune_diseases MRI

http://n.neurology.org/cgi/collection/mri

Information about reproducing this article in parts (figures,tables) or in its entirety can be found online at:

http://www.neurology.org/about/about_the_journal\#permissions

Information about ordering reprints can be found online:

http://n.neurology.org/subscribers/advertise

Neurology ${ }^{\circledR}$ is the official journal of the American Academy of Neurology. Published continuously since 1951, it is now a weekly with 48 issues per year. Copyright . All rights reserved. Print ISSN: 0028-3878. Online ISSN: 1526-632X.

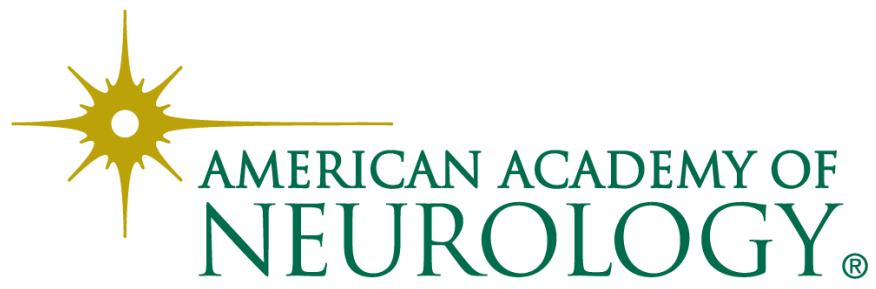

